\title{
Milligram per Liter per Milligram
}

National Cancer Institute

\section{Source}

National Cancer Institute. Milligram per Liter per Milligram. NCI Thesaurus. Code C85710.

Milligrams per liter per milligram. 